\title{
ELDERLY VICTIMS DYING OF UNNATURAL CAUSES: A RETROSPECTIVE DESCRIPTIVE STUDY FROM RAGAMA, SRI LANKA
}

Kitulwatte I.D.G, Paranavithana S.S, Perera A.A.B.S \& Edirisinghe P.A.S

Department of Forensic Medicine, Faculty of Medicine, University of Kelaniya, Ragama, Sri Lanka

Corresponding Author: Kitulwatte I.D.G

Email: indiradgk@yahoo.com (iD https://orcid.org/0000-0002-6108-9059

\section{ABSTRACT}

Even though life expectancy among the elderly has been improving health hazards due to unnatural causes are a significant medical and social issue among this group.

The objective was to determine the causes and epidemiological aspects of unnatural deaths in the elderly.

A retrospective descriptive study conducted for a period of 3 years, at a tertiary care hospital of Sri Lanka where information was collected from hospital records and post mortem reports of persons above 60 years of age, who died due to unnatural causes revealed that a majority of deaths were due to road traffic accidents of pedestrians.

Key words:

Unnatural Deaths, Elderly, Road Accidents, Suicides, Homicides.

All articles in Sri Lanka Journal of Forensic Medicine, Science \& Law are licensed under the terms of the licensed under a Creative Commons Attribution-Non Commercial 4.0 International License. 


\section{INTRODUCTION}

Although ageing is a dynamic biological process beyond human control, defining old age has been widely debated because it is related to the functional ability of the workforce, which can vary with a country's political and economic situation. Many countries define old age as the retirement age i.e. 60 or 65 years. World Health Organization in its working definition defines old age as above 60 years. According to the Department of Census and Statistics of Sri Lanka, there are 2.5.million people, or $12.5 \%$ of the total population above the age of 60 in Sri Lanka. It is estimated that Sri Lanka will have an elderly population of about 3.6 million by 2021, which is $16.7 \%$ of the total population. ${ }^{1}$ Elderly or old age includes ages reaching or exceeding the average life span of human beings. It is expected that the country is going to face many challenges due to this rapidly increasing ageing population. While frequently observed natural illnesses associated with old age such as Alzheimer's disease, cardiovascular diseases, cancer, arthritic conditions and osteoporosis and physical disabilities are expected to rise and pose a significant burden on the health budget, there are many unnatural conditions causing ill-health among these individuals. These unnatural conditions causing ill health in the elderly do consume a disproportionate quantum of medical resources due to physiological changes associated with ageing. Even low energy trauma can be lethal among the elderly due to preexisting medical conditions, age associated diminished respiratory and cardiovascular reserve/functions and insufficient ability for systemic compensation. . $^{2,4}$

Every year, over a million and a half people worldwide die from preventable unnatural causes or acts of violence, that include 800 000 suicides, 50000 homicides and 300000 war deaths. ${ }^{5}$ On the other hand, when deaths occur due to unnatural reasons i.e.
External causes such as injury/trauma or poisoning etc., and where the manner/ circumstance could be homicidal, suicidal or accidental, there is an immeasurable impact on the society, and the lives of the survivors are often changed irrevocably by these tragedies. ${ }^{6,7,8,9}$ This is especially true for the young. However, when the victim is old and friable the public interest in such deaths may not be the same as that for the young. On the other hand, due to the serious, chronic illnesses suffered by these victims, attending physicians are often happy to sign death certificates without personally investigating the circumstances. Thus, unnatural deaths of the elderly are significantly underreported. ${ }^{10}$ On the other hand, the forensic pathologist may face a challenge in assisting to investigate the circumstances of death in elderly due to many natural conditions contributing to the death of these victims.

\section{OBJECTIVES}

To determine the epidemiological aspects, causes, mechanisms of injury and the contribution of natural co-morbidities in unnatural deaths in the elderly.

\section{METHODOLOGY}

Data were collected retrospectively for a period of 3 years, from hospital records and post mortem reports of a tertiary care hospital of Sri Lanka regarding persons above 60 years of age, who died due to unnatural causes. The historical details, scene findings, autopsy findings, investigations, opinion and conclusions given were obtained. Cases where data was incomplete or doubtful were excluded from the study. 


\section{RESULTS}

\section{Table 1: Age distribution}

Fifty five $(\mathbf{5 9 . 8 \%})$ were male and 37 $(40.2 \%)$ female. Majority $24(26 \%)$ were of the age group of 65 - 69 followed by $70-74(23 \%)$. The frequency of deaths due to unnatural causes were less among persons over 75 years of age. (Table 1).

\begin{tabular}{|l|c|c|}
\hline $\begin{array}{l}\text { Age group } \\
\text { (Yrs.) }\end{array}$ & Number & Percentage \\
\hline $60-64$ & 20 & 22 \\
\hline $65-69$ & 24 & 26 \\
\hline $70-74$ & 21 & 23 \\
\hline $75-79$ & 14 & 15 \\
\hline$>80$ & 13 & 14 \\
\hline Total & 92 & 100 \\
\hline
\end{tabular}

Table 2: Circumstances of death

Majority of deaths were accidental $63(68 \%)$ followed by suicidal 21 (23\%) (Table:2)

\begin{tabular}{|l|c|c|}
\hline Circumstances & Number & $\mathbf{\%}$ \\
\hline Accident & 63 & 69 \\
\hline Suicide & 21 & 23 \\
\hline Homicide & 5 & 5 \\
\hline No data & 3 & 3 \\
\hline Total & 92 & 100 \\
\hline
\end{tabular}

Table 3: Management details

While a majority $43(47 \%)$ of victims had received initial treatment at the Emergency Treatment Unit (ETU) or the surgical ward, $41(45 \%)$ were brought dead to the hospital (Table:3).

\begin{tabular}{|l|c|c|}
\hline Received treatment & Number & $\%$ \\
\hline Emergency care only & 1 & 1 \\
\hline ETU/Ward & 43 & 47 \\
\hline $\begin{array}{l}\text { Specialized } \\
\text { care/surgery/ICU }\end{array}$ & 3 & 3 \\
\hline Brought dead to hospital & 41 & 45 \\
\hline No data & 4 & 4 \\
\hline Total & 92 & 100 \\
\hline
\end{tabular}

Table 4: Location of injuries

\section{Injuries were located in multiple body parts in 31 $(34 \%)$ or on the head and neck in a majority 26(28\%). (Table:4).}

\begin{tabular}{|l|c|c|}
\hline Location of injuries & Number & \% \\
\hline Head, face and neck & 26 & 28 \\
\hline Chest and abdomen & 5 & 5 \\
\hline Multiple body parts & 31 & 34 \\
\hline No external injuries & 9 & 10 \\
\hline Chest only & 1 & 1 \\
\hline Abdomen only & 1 & 1 \\
\hline Lower limb & 3 & 3 \\
\hline Head and chest & 6 & 7 \\
\hline Head, chest and abdomen & 10 & 11 \\
\hline Total & 92 & 100 \\
\hline
\end{tabular}

Table 5: Cause of death 
Cause of death in a majority of cases $34(37 \%)$ was cranio-cerebral injuries (Table :5).
There was a history of natural disease in a majority $51(55 \%)$ with many suffering from ischaemic heart disease $34(37 \%)$ (Table :6).

However, natural pathology contributed to death in only $8(9 \%)$.
Most accidental deaths were due to road accidents $\quad 50 \quad(\mathbf{7 9} .3 \%)$ followed by falls from a height $3(4.8 \%)$.

(Table: 7 )

\begin{tabular}{|l|c|c|}
\hline \multicolumn{1}{|c|}{ Cause of death } & Number & \% \\
\hline Craniocerebral injury & 34 & 37 \\
\hline Other & 2 & 2 \\
\hline Unascertained & 1 & 1 \\
\hline Snake bites & 3 & 3 \\
\hline No data & 1 & 1 \\
\hline Chest injury & 4 & 4 \\
\hline Abdominal injury & 1 & 1 \\
\hline Multiple injuries & 17 & 19 \\
\hline Neck compression & 6 & 7 \\
\hline Drowning & 8 & 9 \\
\hline Shock and haemorrhage & 4 & 4 \\
\hline Burn & 3 & 3 \\
\hline Poisoning & 8 & 9 \\
\hline Total & 92 & 100 \\
\hline
\end{tabular}

Table 6: Past medical history

\begin{tabular}{|l|c|c|}
\hline $\begin{array}{l}\text { Presence of a natural } \\
\text { disease }\end{array}$ & Number & $\%$ \\
\hline Hypertension & 5 & 5 \\
\hline $\begin{array}{l}\text { Diabetes mellitus and } \\
\text { hypertension }\end{array}$ & 3 & 3 \\
\hline Ischaemic Heart Disease & 21 & 23 \\
\hline HT/DM/IHD & 5 & 54 \\
\hline IHD and HT & 8 & 9 \\
\hline Other & 9 & 10 \\
\hline None & 41 & 45 \\
\hline Total & 92 & 100 \\
\hline
\end{tabular}

Table 7: Type of accidental death

\begin{tabular}{|l|c|c|}
\hline $\begin{array}{l}\text { Type of accidental } \\
\text { death }\end{array}$ & Number & $\%$ \\
\hline Road Accident (RTA) & 50 & 79 \\
\hline Fall from height & 3 & 5 \\
\hline Burns & 2 & 3 \\
\hline Drowning & 2 & 3 \\
\hline Railway accident & 1 & 2 \\
\hline Other (snake bites, etc.) & 5 & 8 \\
\hline Total & 63 & 100 \\
\hline
\end{tabular}


Table 8: Type of suicidal death

A majority of suicides were due to poisoning 8 $(38.1 \%)$ followed by hanging $6(28.6 \%)$, drowning $4(19 \%)$, rail track trauma $2(9.5 \%)$ and burns 1 (4.8\%). (Table: 8$)$

\begin{tabular}{|l|c|c|}
\hline Type of suicidal death & Number & \% \\
\hline Poisoning & 8 & 38 \\
\hline Hanging & 6 & 29 \\
\hline Drowning & 4 & 19 \\
\hline Burns & 1 & 5 \\
\hline Railway accident & 2 & 10 \\
\hline Total & 21 & 100 \\
\hline
\end{tabular}

Table 9: Victim profile in road accidents

Most of the victims of road accidents $37(74 \%)$ were pedestrians. (Table: 9 )

\begin{tabular}{|l|c|c|}
\hline Victims in RTA & Number & $\%$ \\
\hline Pedestrian & 37 & 74 \\
\hline Driver & 6 & 12 \\
\hline Passenger & 7 & 14 \\
\hline Total & 50 & 100 \\
\hline
\end{tabular}

Table 10: Age distribution of different types of accidental deaths

Road accidents
were commonly
observed among
the age group of
$65-74(54 \%)$ while
there was no
significant age
preponderance in
other types of
accidents.
(Table: 10)

\begin{tabular}{|l|c|c|c|c|c|c|}
\hline Age Type & 60- 64 & $\mathbf{6 5 - 6 9}$ & $\mathbf{7 0 - 7 4}$ & $\mathbf{7 5 - 7 9}$ & $\mathbf{> 8 0}$ & Total \\
\hline RTA & 9 & 12 & 15 & 8 & 6 & 50 \\
\hline $\begin{array}{l}\text { fall from } \\
\text { height }\end{array}$ & 2 & 0 & 0 & 1 & 0 & 3 \\
\hline Burns & 0 & 0 & 1 & 0 & 1 & 2 \\
\hline Drowning & 1 & 1 & & & & 2 \\
\hline $\begin{array}{l}\text { Railway } \\
\text { accident }\end{array}$ & 0 & 1 & 0 & 0 & 0 & 1 \\
\hline Other & 1 & 1 & 0 & 1 & 2 & 5 \\
\hline total & 13 & 15 & 16 & 10 & 9 & 63 \\
\hline
\end{tabular}

Table 11: Age distribution of suicidal deaths

Suicidal deaths were commonly observed in the 60- 64 age group (Table: 11). The reason for suicide was not known by the relatives in a majority.

\begin{tabular}{|c|c|c|}
\hline Age group (yrs.) & $\begin{array}{l}\text { Number of } \\
\text { suicides }\end{array}$ & $\%$ \\
\hline $60-64$ & 6 & 29 \\
\hline $65-69$ & 4 & 19 \\
\hline $70-74$ & 4 & 19 \\
\hline $75-79$ & 4 & 19 \\
\hline$>80$ & 3 & 14 \\
\hline Total & 21 & 100 \\
\hline
\end{tabular}


Elderly victims subjected to trauma or violence have an increased risk of death in relation to their younger counterparts and are more likely to die of medical complications. Study revealed that the sex ratio of unnatural deaths of elderly follows the national statistics where most of the unnatural deaths are recorded among the males compared to the females. ${ }^{11}$ This is shown in studies done in other countries as well. ${ }^{12}$ This could be explained by the lifestyle and behavioral risks of men compared to women.

Study revealed that a majority of the victims were less than 75 years old or in an independently mobile age group. Accidental deaths predominate followed by suicides. The same pattern was observed in studies done in other countries. ${ }^{13,14}$

A majority had died on the spot or had lived until they got basic initial management which indicates the seriousness of their injuries. This can be further explained by the presence of multiple injuries or cranio cerebral injuries in a majority. This contrasts with studies worldwide, where it was highlighted that injuries to the extremities are the commonest type of injury in elderly. ${ }^{15}$

Demetriades D et al has revealed that the survival of elderly patients after trauma could be improved with early intensive monitoring, evaluation and resuscitation. ${ }^{16}$ Thus, the victims with injuries to the extremities may have survived with resuscitation and may not have been included in the study.

A majority had a past medical history of a significant illness, especially ischaemic heart disease. Elderly patients and in particular those with pre-existing medical conditions are known to be at an increased risk of mortality following injuries of minor to moderate severity. ${ }^{17}$ However, the contribution of such natural conditions to the cause of death was identified in only $9 \%$.
This further confirms the seriousness of the injuries where injuries themselves were lethal enough to cause death.

Of all accidental deaths, $79 \%$ were road accidents where the victims were mainly pedestrians. Similar patterns were observed among the elderly in a study done in neighboring India. ${ }^{18}$ National Statistics of Sri Lanka show that there is an increasing trend of road accidents in Sri Lanka. However the majority of victims are drivers or riders, followed by pedestrians, irrespective of age. ${ }^{12}$ This pattern among elderly can be explained by the fact that many do not engage in driving and the fact that due to associated medical conditions or disabilities they are more prone to accidents as pedestrians. Falls are the second most common form of accidental death followed by burns and drowning but the number is significantly low. Accidental falls are identified as an important cause of morbidity and mortality in elderly. ${ }^{19,20}$ Similarly, the fact that aged patients are vulnerable to burn injury, and have far worse treatment outcomes compared to young adults is generally agreed. ${ }^{21}$

The study showed that there is a significant risk of suicide among the elderly where most (29\%) are of the age group of $60-64$ or just after retirement. A majority had consumed a poison. However, suicide in old age is a much neglected area worldwide due to lack of knowledge among the physicians. $^{22}$

Sri Lanka shows the $4^{\text {th }}$ highest suicide rate in the world ${ }^{23}$ and during 2010 to 2012 there was an increasing trend of suicides with age. According to the World Health Organization, in most countries, suicide rates tend to rise as a function of age for both men and women. ${ }^{24}$

Though there is a significant decrease of pesticide poisoning after 1995 in Sri Lanka, even in 2011, it remains the commonest method of suicide, followed by hanging, 
which was highlighted in our study as well. ${ }^{25}$ Elderly people select the easily accessible modes as methods of suicide, and in most developed countries, with the presence of skyscrapers, falls from a height are much commoner. ${ }^{26}$ Our study revealed that there is a significant number of suicidal deaths due to drowning as well. Sri Lanka, being an island with ample resources of water with easy access may make this possible for the elderly.

It is important to study the unnatural circumstances of death among senior citizens of a country to identify the reasons for the untimely, unnatural mortality in order to plan appropriate intervention strategies. Further, this will create awareness among the public of such possibilities, which in turn will give serious concern to the death of the elderly. The study revealed that the majority of these unnatural deaths are due to road accidents, where elderly victims were pedestrians, highlighting the need for supervised transportation. On the other hand, the presence of a significant number of suicides among elderly emphasizes the need for counseling services targeting this group.

\section{REFERENCES}

1. Population and Housing. Department of Census and Statistics- Sri Lanka. 2018 [cited 19 May 2018]. Available from: http://www.statistics.gov.lk/page.asp?page= Population\%20and\%

2. Bakke HK, Dehli T, Wisborg T. Fatal injury caused by low-energy trauma-a 10-year rural cohort. Acta Anaesthesiologica Scandinavica. 2014 Jul;58(6):726-32. https://doi.org/10.1111/aas.12330

3. Chang W, Tsai S, Su Y, Huang C, Chang K, Tsai C. Trauma Mortality Factors in the Elderly Population. International journal of gerontology. 2008 Mar 01;2(1):11-7. https://doi.org/10.1016/S1873-9598(08) 70003-6
4. Broos P, D'Hoore A, Vanderschot P, Rommens P, Stappaerts K. Multiple trauma in elderly patients. Factors influencing outcome: importance of aggressive care. Injury. 1993 Jul 01;24(6):365-8. https://doi.org/10.1016/0020-1383(93) 90096-O

5. Milestones in changing the face of violence prevention [Internet]. Geneva: World Health Organization; 2005. Available from:

http://apps.who.int/iris/bitstream/handle/106 65/43313/9241593555_eng.pdf;jsessionid=5 B72F5B40664477F1CC32C5B5B7250E8?s equence $=1$

6. Natural \& unnatural deaths. Coronial Services of New Zealand [Internet]. 2016 [cited 19 May 2018]. Available from: https://coronialservices.justice.govt.nz/whatto-expect-during-an-inquiry/natural-andunnatural-deaths/

7. Krug E, Dahlberg L, Mercy J, Zwi A, Lozano R. World report on violence and health. [Internet]. Geneva: World Health Organization; 2002 [cited 19 May 2018]. Available from: http://apps.who.int/ iris/bitstream/10665/42495/1/9241545615_e ng.pdf

8. Injuries and violence: the facts [Internet]. Geneva: World health organization; 2010 [cited 19 May 2018]. Available from: http://apps.who.int/iris/bitstream/10665/442 88/1/9789241599375_eng.pdf

9. Segen J. Concise dictionary of modern medicine. New York: The McGraw-Hill Companies; 2002.

10. Corey T, Weakley-Jones B, Nichols G, Theuer H. Unnatural Deaths in Nursing Home Patients. Journal of forensic sciences. 1992 Jan 01;37(1): 222-7. ttps://doi.org/10.1520/JFS13229J

11. Satharasinghe A. Statistical Abstract 2016 [Internet]. Department of Census and Statistics. 2018 [cited 19 May 2018]. Available from: http://www.statistics.gov.lk/Abstract2016/in dex.asp 
12. Wilkins K. Causes of death: How the sexes differ [Internet]. Statistics Canada; 1995. Available from: http://www.statcan.gc.ca/pub/82-003x/1995002/article/2509-eng.pdf

13. Kumar S, Verma A. A study of elderly unnatural deaths in medico-legal autopsies at Lucknow locality. Medicine, science, and the law. $2014 \mathrm{Jul} ; 54(3): 127-31$.

https://doi.org/10.1177/0025802413502783

14. Eilertsen HH, Lilleng PK, Mæhle BO, Morild I. Unnatural death in the elderly. Forensic science, medicine, and pathology. 2007 Mar 1;3(1):23-31. https://doi.org/10.1385/FSMP:3:1:23

15. Santos AM, Rodrigues RA, Diniz MA. Trauma in the elderly caused by traffic accident: integrative review. Revista da Escola de Enfermagem da U S P. 2015 Feb;49(1):162-72. http://dx.doi.org/10.1590/S0080623420150000100021

16. Demetriades D, Karaiskakis M, Velmahos G, Alo K, Newton E, Murray J, Asensio J, Belzberg H, Berne T, Shoemaker W. Effect on outcome of early intensive management of geriatric trauma patients. The British journal of surgery. 2002 Oct;89(10):1319$22 . \quad$ https://doi.org/10.1046/j.13652168.2002.02210.x

17. Hollis S, Lecky F, Yates DW, Woodford M. The effect of pre-existing medical conditions and age on mortality after injury. The journal of trauma and acute care surgery. 2006 Nov 1;61(5): 125560.

https://doi.org/10.1097/01.ta.0000243889.07 090.da

18. Chaudhary B, Vidua R, Kumar A, Bajaj A. A Study on Mortality Profile among Fifty Plus- (50+-) Population (FPP) of India: A 5Year Retrospective Study at New Delhi District. Current gerontology and geriatrics research. 2016;2016:1-5. http://dx.doi.org/10.1155/2016/6403103
19. Kumar A, Verma A, Yadav M, Srivastava A. Fall: The Accidental Injury in Geriatric Population. Journal of Indian Academy of Forensic Medicine. 2011;33(2):175-8. Available from:

http://medind.nic.in/jal/t11/i2/jalt11i2p175.p df

20. Antes D, Schneider I, d'Orsi E. Mortality caused by accidental falls among the elderly: a time series analysis. Revista Brasileira de Geriatria e Gerontologia. 2015 Dec;18(4):769-78.

http://dx.doi.org/10.1590/1809-9823. 2015.14202

21. Keck M, Lumenta D, Andel H, Kamolz L, Frey M. Burn treatment in the elderly. Burns. 2009 Dec 01;35(8):1071-9. https://doi.org/10.1016/j.burns.2009.03.004

22. Heisel M, Duberstein P. Suicide Prevention in Older Adults. Clinical Psychology: Science and Practice. 2005 Sep 01;12(3):242-59.

https://doi.org/10.1093/clipsy.bpi030

23. Knipe D, Metcalfe C, Gunnell D. WHO suicide statistics - a cautionary tale. The Ceylon medical journal. 2015 Mar 17;60(1):35.

24. Mental Health: Suicide data [Internet]. World Health Organization. 2018 [cited 15 August 2010]. Available from: http://www.who.int/mental_health/preventio n/suicide/suicideprevent/en/.

25. Knipe D, Metcalfe C, Fernando R, Pearson M, Konradsen F, Eddleston M et al. Suicide in Sri Lanka 1975-2012: age, period and cohort analysis of police and hospital data. BMC Public Health [Internet]. 2014 [cited 19 May 2018];14(1). Available from: https://doi.org/10.1186/1471-2458-14-839

26. Abrams RC, Marzuk PM, Tardiff K, Leon AC. Preference for fall from height as a method of suicide by elderly residents of New York City. American Journal of Public Health. 2005 Jun;95(6):1000-2. DOI: 10.2105/AJPH.2004.037861 